\title{
The Effect of Credit Usage on Touristic Consumption and Application in Turkey
}

\author{
Kudret Gul', Melike Gul² \\ ${ }^{1}$ Tourism and Hotel Management Department, Balikesir Vocational School, Balikesir University, Balikesir, \\ Turkey \\ ${ }^{2}$ Tourism and Hotel Management Department, Sindirgi Vocational School, Balikesir University, Balikesir, Turkey \\ Email: kgul@balikesir.edu.tr, melikegul@mynet.com
}

Received 11 January 2015; accepted 26 January 2015; published 30 January 2015

Copyright (C) 2015 by authors and OALib.

This work is licensed under the Creative Commons Attribution International License (CC BY). http://creativecommons.org/licenses/by/4.0/

(c) (i) Open Access

\section{Abstract}

Turkish tourism was developed as more dependent on external demand until the 2000s. With the effect of increase in demand of domestic tourism, Turkish tourism has gained more stable and more balanced structure in the early 21st century. Economic stability in recent years, personal income growth, developments in the banking and finance sector play an important role in this increase in demand for domestic tourism. In parallel to these developments in Turkey, increasing use of consumer credit has increased significantly domestic and international tourism demand of the Turkish citizens in the last 10 years. In our study, taking account these developments in Turkish tourism, the effect of the use of consumer credit for touristic consumption is to determine for domestic and foreign tourism in Turkey.

\section{Keywords}

Tourism Demand, Touristic Consume, Individual Income, Consumer Credits, Individual Credits, Travel Credits

Subject Areas: Business Finance and Investment, Managerial Economics, Monetary Economics

\section{Introduction}

Unstored features of touristic goods and services, the need to be consumed where they are produced [1]-[3], and demand sensitivity [4] make selling pressure on tourist enterprises. Even though the long-term income of people is sufficient for travel, short-term cash shortages could prevent this. The travel that are not made today (even though will made in the future), because of this characteristics of tourist goods and services, tourism business can not compensate for the losses. At this point, consumer loans are becoming more and more important for the tourism sector. 
Consumer credit plays an important role in the evaluation of all kinds of selling opportunities that emerged in reducing this selling pressure. On the other hand, one of main functions of banks is to funding markets. Thus, loan demand for tourist consumption is creating a significant potential for banks. Consumer credit also allows pre-financing for consumer demand. As a result, all parties benefit on consumer credit in financial sector.

The structure of the financial system in a country plays an important role in the increase of the tourism demand. The positive developments that affect tourist demand with the presence of financial institutions willing to finance tourist consumption increase tourist consumption. One of the most influential financial instruments in the financial system that effect touristic spend is the credit [5].

Increasing economic stability in the economy, decline inflation, falling interest rates and increasing global liquidity has reduced banks' cost of funds in recent years in Turkey's economy. These developments have facilitated access to credit needs of consumers. These developments have also led to an increase in tourist consumption together with demand for consumer loans [6]. Due to these developments, the change in the economic structure and financial system plays an active role in the increase of touristic consumption.

In this study, firstly, we examined both domestic and foreign tourism income and expenditure trends in Turkey. Secondly, we tried to determine relationship between tourist consumption and consumer credit usage. Finally, we evaluated the effect of credit usage on tourist consumption in Turkey.

The study aimed to determine the existing situation with a descriptive method.

\section{Tourist Consumption Trends in Turkey}

As of the end of 2013 the number of tourists visiting Turkey is 39.2 million and tourism revenues were $\$ 32.3$ Billion. $78.9 \%$ of these revenues were obtained from foreign visitors and $21.1 \%$ of the citizens residing abroad. On the other hand, the number of Turkish citizens who travelled abroad was 7.5 million, while their spending was $\$ 5.2$ billion in 2013 [7].

As seen Table 1, the number of visitors to Turkey has increased annually 9.17\% in the last 11 years. In the same period, the rate of increase in international tourism income is $8.83 \%$. These data indicate that rate of increase in international tourism revenue has remained lower than $0.34 \%$ from the rate of increase in the number of visitors. On the other hand, the increase rate of travels abroad from Turkey is $8.22 \%$ and annual increase in foreign tourism expenditure ratio is $8.04 \%$ in the last 11 years. Also it can be observed from the table below that there is a significant increase in both internal and external tourism revenues and expenses with the exception of some years in the past 11 years. These growth rates are quite high when compared with the growth rate in world GDP of $2.7 \%$ [8] between the years $2000-2011$ and $4.98 \%$ in Turkey's economy between the years of 20032013 [9]. Thus, the factors that influence tourist demand have been improved positively in the same period in Turkey.

Table 1. Domestic and international tourism income-expenditure in Turkey, 2003-2013.

\begin{tabular}{|c|c|c|c|c|c|c|c|c|c|c|c|c|}
\hline Year & $\begin{array}{l}\text { Number of } \\
\text { Foreign } \\
\text { Visitors }\end{array}$ & $\begin{array}{c}\Delta \\
(\%)\end{array}$ & $\begin{array}{c}\text { Int. } \\
\text { Tourism } \\
\text { Income } \\
\text { (Million \$) }\end{array}$ & $\begin{array}{c}\Delta \\
(\%)\end{array}$ & $\begin{array}{l}\text { Travels } \\
\text { Abroad }\end{array}$ & $\begin{array}{c}\Delta \\
(\%)\end{array}$ & $\begin{array}{c}\text { Int. } \\
\text { Tourism } \\
\text { Expend. } \\
\text { (Million \$) }\end{array}$ & $\begin{array}{c}\Delta \\
(\%)\end{array}$ & $\begin{array}{c}\text { Num of } \\
\text { Dom. } \\
\text { Travel } \\
(1000)\end{array}$ & $\begin{array}{c}\Delta \\
(\%)\end{array}$ & $\begin{array}{c}\text { Dom. } \\
\text { Tourism } \\
\text { Expend. } \\
\text { (Million TL) }\end{array}$ & $\begin{array}{c}\Delta \\
(\%)\end{array}$ \\
\hline 2003 & 16302053 & - & 13854 & - & 3414844 & - & 2424 & - & - & - & - & - \\
\hline 2004 & 20262640 & 24.3 & 17076 & 23.2 & 3844494 & 12.5 & 2954 & 21.8 & - & - & - & - \\
\hline 2005 & 24124501 & 19.0 & 20322 & 19.0 & 4124829 & 7.2 & 3394 & 14.8 & - & - & - & - \\
\hline 2006 & 23148669 & -4.0 & 18593 & -8.5 & 4063180 & -1.4 & 3270 & -3.6 & - & - & - & - \\
\hline 2007 & 27214988 & 17.5 & 20942 & 12.6 & 4956069 & 21.9 & 4043 & 23.6 & - & - & - & - \\
\hline 2008 & 30979979 & 13.8 & 25415 & 21.3 & 4892717 & -1.2 & 4266 & 5.5 & - & - & - & - \\
\hline 2009 & 32006149 & 3.3 & 25064 & -1.3 & 5561355 & 13.6 & 5090 & 19.3 & 60888 & - & ${ }^{* *} 12216$ & - \\
\hline 2010 & 33027943 & 3.1 & 24930 & -0.5 & 6557233 & 17.9 & 5874 & 15.4 & 68373 & 12.2 & 13843 & 13.3 \\
\hline 2011 & 36151328 & 9.4 & 28115 & 12.7 & 6281972 & -4.1 & 5531 & -5.8 & 65854 & -3.6 & 15641 & 12.9 \\
\hline 2012 & 36776645 & 1.7 & 29351 & 4.3 & 5802950 & -7.6 & 4593 & -16.9 & 64922 & -1.4 & 16725 & 6.9 \\
\hline 2013 & 39226226 & 6.6 & 32310 & 10.0 & 7525869 & 29.6 & 5253 & 14.3 & 68452 & 5.4 & 18416 & 9.1 \\
\hline \multicolumn{2}{|c|}{ Annual $\Delta(\%)^{*}$} & 9.17 & & 8.83 & & 8.22 & & 8.04 & & 2.97 & & 10.8 \\
\hline
\end{tabular}

${ }^{*}$ Annual $\Delta \%=(\sqrt[n]{x / y}-1) 100$. In formula, $n$ : years; $x$ : the value belong to the last year; $y$ : the value belong to first year. ${ }^{* *}$ TurkStat has been monitored the number of domestic travels and domestic tourism expenditures since 2009. Source: TurkStat. 
The data also show that despite the reduction in overseas spending in some years, the upward trend continued in international tourism demand and tourism spending. The annual increase rate in number of the domestic travels has been $2.97 \%$ in the last 5 years. In contrast, the annual increase in domestic tourism spending is $10.8 \%$ in the same period. These results show that citizens traveling for internal tourism abroad have spent much more per capita in the same period.

Tourist consumption requires the presence of a certain amount of disposable income, even after the mandatory requirements are met. Therefore, the most important source of financing of the tourism demand is the personal income. Usal and Oral (2001) qualifies the tourist consumption as a socio-cultural type of consumption and today tourist consumption is still widely regarded as a luxury consumption.

The surveys are conducted on household consumption expenditure by Turkey Statistical Institute to produce data about the consumption habits of consumers, disposable income of households and income distribution amoung individuals [10]. Therefore, these data provide important clues about monitoring the change in tourist expenditures which related with tourist consumtion items directly or indirectly.

Change in expenditure elasticity compared with income is less than 1 and is argued to be mandatory expenditures. If expenditure elasticity is bigger than 1, these expenditure groups are considered as luxury. In a study conducted by Tari and Pehlivanoglu in 2006 [11] in accordance with these criteria that associated with luxury consumption expenditure elasticity, it was found 1.26 for "Hotels and restaurants" spending, 1.57 for "transportation" spending and 1.73 for "culture-entertainment" spending. In the same survey, when income increases, the share of mandatory spending decreases and whereas the share of luxury spending increases on consumer budgets.

By analyzing the distribution of consumption expenditure of households in the past 5 years in Turkey, the average spending luxury consumption seems to be an increase of $1.3 \%$ per year on the basis of 2008. Meanwhile, mandatory consumption expenditure is decreased $-1.7 \%$ every year in the same period (see Table 2). On the other hand, share of expenditure of entertainment and culture when compared to total expenditure is $2.76 \%$ in the last 5 years. This rate is $5.3 \%$ in the restaurants and hotels expenditures in the same period. Thus, spending related to tourist consumption is $8.06 \%$ of total expenditure in Turkey. Although different calculation methods and methodologies is used from Turkey, the recreation spending is $6.69 \%$ of total expenditure in the United States. Restaurants, hotels and foreign travel expenses is $6.66 \%$ of the total expenditure [12]. Thus, spending related to tourist consumption is $13.35 \%$ of total expenditure in USA. This result indicates that spending related to tourist consumption increases depending on high income per capita among countries as specified in the literature [13].

The above data show that tourist consumption expenditures have increased significantly compared to mandatory spending in recent years. In domestic tourism in 2013, a total of 68 million 452 thousand citizens traveled and they spent 18 billion 416 million TL. 1274 million TL of these spending consists of package tour expenditure, while 17 million 142 thousand TL consists of individual expenses [14].

As indicated above, a significant increase is observed in both overseas and domestic travel expenses in Turkey in recent years. The positive impact of the factors that affect tourism demand is argued to be effective in these increases, as well as funding under more favorable conditions to tourist consumption.

Table 2. Montly distribution of household consumption expenditures in the Turkish economy, 2008-2012.

\begin{tabular}{|c|c|c|c|c|c|c|c|c|c|c|c|}
\hline 1) Compulsory Expenditure Type & 2008 & $\%$ & 2009 & $\%$ & 2010 & $\%$ & 2011 & $\%$ & 2012 & $\%$ & $\Delta \%$ \\
\hline Food and Non-Alcoholic Drink & 368 & 22.6 & 388 & 23.0 & 403 & 21.9 & 439 & 20.7 & 464 & 19.6 & -0.750 \\
\hline Housing and Rent & 472 & 29.1 & 477 & 28.2 & 500 & 27.1 & 547 & 25.8 & 611 & 25.8 & -0.925 \\
\hline Health & 31 & 1.9 & 32 & 1.9 & 39 & 2.1 & 40 & 1.9 & 43 & 1.8 & -0.025 \\
\hline Share of Total & 871 & 53.6 & 897 & 53.1 & 942 & 51.1 & 1026 & 48.4 & 1118 & 47.2 & -1.700 \\
\hline \multicolumn{12}{|l|}{ 2) Expenditure As Luxury Type } \\
\hline Transportation & 229 & 14.1 & 229 & 13.6 & 278 & 15.1 & 365 & 17.2 & 406 & 17.2 & 0.775 \\
\hline Entertainment and Culture & 41 & 2.5 & 44 & 2.6 & 51 & 2.8 & 57 & 2.7 & 77 & 3.2 & 0.175 \\
\hline Restaurants and Hotels & 71 & 4.4 & 87 & 5.2 & 100 & 5.4 & 121 & 5.7 & 137 & 5.8 & 0.350 \\
\hline Share of Total & 341 & 21.0 & 360 & 21.4 & 429 & 23.3 & 543 & 25.6 & 620 & 26.2 & 1.300 \\
\hline 3) Other Substitution Expenditures & 414 & 25.4 & 431 & 25.5 & 472 & 25.6 & 551 & 26.0 & 628 & 26.6 & 0.300 \\
\hline Total Consumption Expenditure & 1626 & 100 & 1688 & 100 & 1843 & 100 & 2120 & 100 & 2366 & 100 & \\
\hline
\end{tabular}

Source: TurkStat. 


\section{Tourist Consumption and Consumer Credit Relationship in Tourism}

Consumer loans are an effective source of financing for tourist consumption. These loans are offered by banks to meet the cash needs of the consumers in this sector. They can be named as the education, housing development, housing renovation, furniture, marriage, health, individual support loans, holiday loans depending on usage. Maturity and interest rate of these loans vary from one bank to the other [15].

The type of loans which can be associated directly with the tourist consumption is the travel credit granted under individual needs. But there is no organization that publishes statistical data related to the travel credit in Turkey. Therefore, it is difficult to establish a direct relationship between changes in holiday loans and tourist consumption expenditure. Because of these difficulties, we will try to determine the relationship between change in consumer loans and domestic/overseas tourism spending. Due to the lack of statistical data, it is referenced by this measurement technique that may give an idea indirectly about the relationship between travel credit and tourist consumption expenditure.

Banks loan figures consists of the difference between the loan amount that are compiled from the credit balance for the period up to the amount of loans granted during the period of repayment in Turkey. In general, fluctuations in current credit movement is directly proportional to the total consumption demand in the economy [16]. Thus, it is possible to establish indirect relationship between the increase in consumer loans associated with tourist consumption and the increase in domestic and foreign tourism demand in recent years.

Today, worldwide consumption is more concentrated in urban centers. Inflation and growth are the most important factors affecting the consumption [17]. On the other hand, increasing economic stability, falling inflation and interest rates, global liquidity due to the decreasing cost of funds of banks make easier to access consumer credits for touristic consumers in Turkey's economy in recent years. These developments has led to an increase in tourist consumption and consumer loans.

In a survey conducted by Mercan [18] (2013), it is estimated that 1\% increase in the volume of domestic credit increased growth rate $0.6 \%$ between the years of $1992-2011$ for Turkey's economy. Also in another study conducted by Iscan [19] (2003), it is suggested that 7.2\% growth occurred in the Turkish economy in 2000, loans were increased $19.2 \%$. Whereas $7.3 \%$ contraction experienced in 2001, loans was decreased 36.3\%. On the other hand, when loans are mainly financed by banks in the economy, the credit crunch makes it difficult for the revival of the economy. Therefore, it would be logical to use other financing channels in the financing of tourism demand at the time of economic, political and social crisis.

Country risk depending on economic, financial and political factors affect the tourism market [20]. There is a significant relationship between economic growth and loans in an economy. A similar relationship can be argued with the increase in tourist demand and increase in individual loans used to finance tourist consumption. Similar relationship is also put forward between the increase in consumer credit and increase in tourist consumption. The experiences faced in several countries indicate that rapid individual loans support economic growth. This implies that economic growth has already occurred together with the increase in consumption.

To be able to spend more short-run income for the consumers depends on savings or borrowing facilities. In this context, consumer loans plays an important role in the increase of consumption when individual savings are inadequate. Inag [21] indicate that consumer loans taken consumer preferences forward in time, while the Tekirdag [22] emphasize these loans allows new consumer spending. On the other hand, consumers are more willing to finance the current consumption with using credit. Nowadays, facilitating the use of credit, the benefits of the widespread use of credit and consumer awareness about the risks associated with credit use is supporting this process [23].

The institutions that publish statistical data related to consumer loans in Turkey is Turkish Statistical Institute (TurkStat), the Banking Regulation and Supervision Agency (BRSA), Central Bank of Republic of Turkey (CBRT), Banks Association of Turkey (BAT) and Turkisch Interbank Card Center (ICC). These organizations are discussed housing, vehicle and loans for various needs within the context of consumer credit.

\section{The Effect of Credit Usage on Tourist Consumption in Turkey}

While other conditions are fixed, if the banks decrease interest rate, it increases demand for consumer loans. If they increase interest rate, it reduces the demand for consumer loans. In other words, interest rate is the main factor for determining the demand for consumer loans and degree of its influence was calculated as 53.6\% in Turkey between the years 2004-2009 [24]. Tekirdag (2009) are also sorted the factors affecting the demand for 
credit as interest rates, income, asset accumulation, occupational status, marital status, age, education level, household size and unemployment.

The most important problem for lenders in consumer loans is the risk of these loans. In order to reduce the risk of consumer loans, banks and public authorities can use the capital increase options, limiting the amount of credit and credit risk reduction techniques [25]. On the other hand, the risk of default on consumer loans vary according to the type of loan. Tekirdag (2009) indicates that these risks is quite higher in other consumer loans (including holiday loans) except automobile and housing loans and is related to the level of economic development and stability. In practice in the tourism sector, firms do not undertake any responsibilities on the approval of travel loans to consumers by financial institutions. Banks' travel credit conditions, interest rates and maturities of these rates may vary credit to be granted [26].

Implementing the individual risk report contribute to the solution of the problems encountered for consumer loans in recent years in Turkey. Individual credit risk report that including individuals credit score is a report which outlines individual credit deals in the banking sector. These reports and scores are used all kinds of consumer loans including travel credit and credit cards that are allocated to individuals by banks. The application of credit rating affect credit limit, interest and costs in Turkey. Thus, customers who have high credit scores will pay less interest and expenses in the future [27]. According to Nelson [28] credit score applications that applied for consumer is an important factor in determining customers risk, interest rates and cost of the loans. On the other hand, payment history, credit utilization, credit history, credit used and new credit play crucial role for determining the credit scores [29].

Nowadays, both credit score and credit risk report can be prepared for credit users. These reports make two-way benefit for lenders as well as credit users in terms of minimizing risk [30]. These methods that reducing risk can also be used by tourism businesses. Implementing long term sales policies for customers who have positive credit record and payment habits, will be effective in reducing risk.

Another point to be considered in term of loans are legal regulations about credits use. Legal regulations is not effective to control especially in terms of high-risk borrowers. However, with the impact of the global financial crisis faced worldwide in 2008, many countries are directed to stabilize the financial sector and those new regulations to protect consumers and creditors [31]. According to Hofmann [32] European Union gives emphasis to strategies to ensure transparency for the protection of consumers in all new arrangements. In this context, the annual interest rates on consumer loans and credit conditions relating to different banks can be compared with standard that allows information to ensure. Union also tries to give resposibility to creditors about the consumer credit agreements such as consumers' income, savings, debts and other financial transactions that is related matters to determine the credibility of the customer.

BRSA Financial Market Report-2012 indicates that financial stability, decrease in inflation, increase in purchasing power and rise in long-term positive expectations have increased the debt of households in the the past 11 years. Financial stability period has been increasing real and nominal growth of consumer credit. As of December 2012 in Turkey, household financial liabilities to financial assets ratio has risen to $43.2 \%$ and liabilities to GDP ratio is $17.7 \%$. These rates are manageable risks according to international standart. Individual credit cards and personal loans plays an important role in the growth of consumer credit and the increase in financial liabilities of households in total. In addition, in recent years the decline in interest rates on consumer loans as well as real interest rates is downward, has been increased the loan volume and thus has been a major factor in the growth of domestic demand. Therefore, these developments maybe effective in the increase of domestic tourism demand and perhapsin the having of travel habit of citizens in Turkey in recent years.

Table 3 shows that consumer lending have increased by an annual average of 39.47 in Turkey in the last 11 years. While this growth rate is quite high till seventh year, the rate of increase slowed down in the last three years. Ekinci [33] calculated optimal annual credit growth rate of Turkey as 17\% for the last 20-year period. The increase $39.47 \%$ consumer loans is much higher than the optimal increase $17 \%$ in loans that calculated for Turkey’s economy.

Table 3 shows that annual increase in international tourism expenditure is $8.04 \%$ in Turkey in the last 11 years. The increase in domestic tourism spending is $10.8 \%$ followed by TurkStat since 2009 for the last four years. These rates are much below than the increase $39.47 \%$ in installment loans' growth. In other words, the figures shows that despite the high increases in consumer loans, this increase are not emerging adequately in tourist consumption. Therefore, this weak relationship between consumer loans and tourist consumption, it is thought to be more useful to analyze a sub-category of consumer loans with the establishment of a relationship 
Table 3. Relationship between tourist consupmtion and credit loans in turkey.

\begin{tabular}{|c|c|c|c|c|c|c|c|c|c|}
\hline Year & $\begin{array}{l}\text { Population } \\
\text { (1000) }\end{array}$ & $\begin{array}{c}\text { GNP } \\
\text { (Million } \\
\$ \text { ) }\end{array}$ & $\begin{array}{l}\text { Per Capita } \\
\text { Income (\$) }\end{array}$ & $\Delta(\%)$ & $\begin{array}{c}\text { Household Debt/ } \\
\text { Disposable Income (\%) }\end{array}$ & $\begin{array}{l}\text { Installment } \\
\text { Credit } \\
\text { (Million \$) }\end{array}$ & $\Delta(\%)$ & $\begin{array}{c}\text { Int. Tourism } \\
\text { Expenditure } \\
\Delta(\%)\end{array}$ & $\begin{array}{c}\text { Domestic Tourism } \\
\text { Expenditure } \\
\Delta(\%)\end{array}$ \\
\hline 2003 & 66873 & 304901 & 4559 & - & 7.5 & 4050 & - & - & - \\
\hline 2004 & 67734 & 390387 & 5764 & 26.4 & 12.9 & 9087 & 124.3 & 21.8 & - \\
\hline 2005 & 68582 & 481497 & 7022 & 21.8 & 20.9 & 21236 & 133.6 & 14.8 & - \\
\hline 2006 & 69421 & 526429 & 7586 & 8.0 & 19.0 & 32248 & 51.8 & -3.6 & - \\
\hline 2007 & 70256 & 648625 & 9238 & 21.7 & 22.7 & 50392 & 56.2 & 23.6 & - \\
\hline 2008 & 71517 & 742094 & 10438 & 12.9 & 36.6 & 62721 & 24.4 & 5.5 & - \\
\hline 2009 & 72561 & 616703 & 8559 & -18.0 & 36.4 & 58550 & -6.6 & 19.3 & - \\
\hline 2010 & 73722 & 735828 & 10022 & 17.0 & 41.2 & 83268 & 42.2 & 15.4 & 13.3 \\
\hline 2011 & 74724 & 773980 & 10466 & 4.4 & 44.7 & 97077 & 16.5 & -5.8 & 12.9 \\
\hline 2012 & 75627 & 786293 & 10504 & 0.3 & 48.1 & 103713 & 6.8 & -16.9 & 6.9 \\
\hline 2013 & 76667 & 820012 & 10782 & 2.6 & 55.2 & 112825 & 8.7 & 14.3 & 9.1 \\
\hline \multicolumn{2}{|c|}{ Annual $\Delta(\%)$} & & & 8.98 & & & 39.47 & 8.04 & 10.8 \\
\hline
\end{tabular}

Source: TurkStat, CBRT, BAT.

between tourist consumption. In this study, such a relationship is conceived to fit for holiday loans but there is no systematic data regarding such a calculation could be made adequately.

It can be seen from Table 4 that the annual average growth rate of $31.9 \%$ in consumer loans for the last nine years. This rate is below than the increase in installment loans of $45.0 \%$. But it is quite high than $13.15 \%$ increase in GNP at current price, $10.8 \%$ increase in the domestic tourist consumption expenditures and $8.04 \%$ increase in foreign tourist consumption expenditures. In other words, it is understood that this high increase in consumer loans arise from out of holiday loans.

Income per capita is $11390 \mathrm{TL}$ in 2005 in Turkey, which is increased to 18,834 TL in 2013. So for the last eight years, the rate of increase income per capita in TL terms is $65.3 \%$, while the average annual increase in per capita income is $5.74 \%$. In the same period, the elasticity is 5.01 depend on change in the demand for consumer loans comparing with the income per capita. These results indicate that credit demand is extremely sensitive to income increases in Turkey. No doubt the same will be true for travel loan demand sensitivity.

By considering per capita income increase and consumer loans demand elasticity in the projected period, the increase in the demand for consumer loans and travel loans will continue. Thus, it can be foreseeable that the credit demand for touristic consumption will continue to increase in the coming years and banks will create more business opportunities for the reveal in Turkey.

As of December 2013, amounting to TL 332.2 billion of individual loans consists $74.7 \%$ of installment loans and $25.3 \%$ of the credit card. Installment loans consists $52.1 \%$ of consumer loans and other loans, $44.4 \%$ of housing loans, 3.4\% of vehicle loans [34]. On the other hand, non-mortgage debt, which includes consumer, personal and instalment loans, but also private loans from relatives, friends, employers, etc. is held by $22.4 \%$ of households in Euro Area. Whereas credit lines and credit card debt are much less prevalent, with $10.2 \%$ and $4.3 \%$ of all households reporting such types of debt, respectively [35]. In Turkey, credit card debt ratio is $25.2 \%$. This rate is 20.9\% higher than the Euro Area in Turkey. In order to solve problem, goverment applied restriction policies to decline card expenditures. Due to restrictions on credit card spending that came into force in March 2014, it is estimated that the demand for consumer loans will increase in the coming years. In addition, some banks install long-term consumer credit to POS devices which are relevant as cards spending [36].

Travel credits have been widespread in Turkey in recent years. These credits are one of the individual credit types that extended to consumers by banks to meet social and psychological needs of people with holiday expenses. Maturities and interest rates of these loans vary according to the bank, but the term may be up to a maximum duration of 60 months [37] [38]. In addition, some banks organize campaigns such as increasing the number of installments and defer payment that are valid only for travel spending made by members credit cards in the members workplace [39].

The growth rate of domestic tourism and international tourism expenditure is well above the growth rate of the economy in Turkey in recent years. This high growth rate in tourist consumption is creating new business 
Table 4. Effect of the consumer loans on domestic and int. tourism expenditure.

\begin{tabular}{|c|c|c|c|c|c|c|c|c|c|c|c|}
\hline Year & $\begin{array}{c}{ }^{* * * *} \text { GNP } \\
\text { (Million } \\
\text { TL) }\end{array}$ & $\Delta(\%)$ & $\begin{array}{c}\text { Installment } \\
\text { Credit } \\
\text { (Million TL) }\end{array}$ & $\Delta(\%)$ & $\begin{array}{c}\text { Consumer } \\
\text { Credit } \\
\text { ( Million TL) }\end{array}$ & $\Delta(\%)$ & $\begin{array}{c}\text { Other } \\
\text { Credit } \\
\text { ( Million TL) }\end{array}$ & $\begin{array}{c}\Delta \\
(\%)\end{array}$ & $\begin{array}{c}\text { Int. } \\
\text { Tourism } \\
\text { Exp. } \Delta(\%)\end{array}$ & $\begin{array}{c}\text { Domestic } \\
\text { Tourism } \\
\text { Exp. } \Delta(\%)\end{array}$ & $\begin{array}{l}\text { Income Elasticity } \\
\text { of Demand for C. } \\
\left.\text { Loans ( } E_{\mathrm{g}}\right)\end{array}$ \\
\hline 2003 & 454780 & - & 6048 & - & - & - & - & - & - & - & - \\
\hline 2004 & 559033 & 22.9 & 12925 & 113.7 & - & - & - & - & 21.8 & - & - \\
\hline 2005 & 648931 & 16.1 & 28474 & 120.3 & ${ }^{* *} 9372$ & - & - & - & 14.8 & - & - \\
\hline 2006 & 758390 & 16.9 & 46151 & 62.0 & 15712 & 67.6 & - & - & -3.6 & - & 5.13 \\
\hline 2007 & 843178 & 11.2 & 65586 & 42.1 & 25869 & 64.6 & - & - & 23.6 & - & 8.50 \\
\hline 2008 & 950534 & 12.7 & 81093 & 23.6 & 33526 & 29.5 & - & - & 5.5 & - & 3.63 \\
\hline 2009 & 952558 & 0.2 & 90583 & 11.7 & 40769 & 21.6 & ${ }^{* * *} 596$ & - & 19.3 & - & 6.75 \\
\hline 2010 & 1098799 & 15.4 & 124936 & 37.9 & 45600 & 11.8 & 13675 & - & 15.4 & 13.3 & 1.13 \\
\hline 2011 & 1297713 & 18.1 & 162119 & 29.7 & 62261 & 36.5 & 20275 & 48.2 & -5.8 & 12.9 & 3.31 \\
\hline 2012 & 1416798 & 9.2 & 185906 & 14.6 & 67365 & 8.1 & 27606 & 36.1 & -16.9 & 6.9 & 2.51 \\
\hline 2013 & 1565180 & 10.5 & 248357 & 33.5 & 85893 & 22.2 & 36001 & 21.2 & 14.3 & 9.1 & 9.19 \\
\hline \multicolumn{2}{|c|}{ Annual $\Delta(\%)$} & 13.15 & & 45.0 & & 31.9 & & 38.0 & 8.04 & 10.8 & 5.01 \\
\hline
\end{tabular}

*ICC data covers the data of member of deposit banks, and development and investment banks. Data provided can vary depending on the number of banks and years. ${ }^{* *}$ In previous years, installment loans have been followed as auto, mortgage and other loans. Then, consumer loans have been followed under a separate heading since $2005 .{ }^{* * *}$ These group cover out of vehicles, mortgage and consumer loans that can not be classified in any of the types of consumer credit. Travel loans is under in this group and classified as one of the types of other consumer loans. Consumer loans began to be monitored as loans of the marriage, loans of the durable and semi-durable goods, education loans and health loans since 2009. But first year data seems unreliable and inadequate. It is not used in the analyze. ${ }^{* * * *}$ Expenditure on the Gross Domestic Product at current prices. Source: TurkStat, CBRT, BAT*, BRSA.

opportunities for banks in the market. Supporting this new credit market by banks and other funding sources has great importance in terms of the stability for tourist consumption. This process will be contribute to market expansion and deepening. But there are needs to gather reliable and sufficient data in this area. In this context, related organizations such as the ICC, CBRT and TurkStat are extremely important to produce the necessary statistical data. Thus, the effect of using travel credit on the increase in tourist consumption may be easily examined.

\section{Results}

One of the most influential financial instruments in the financial system that affect the increase in touristic consumption is the credit. Increasing economic stability in the economy, decline inflation, falling interest rates and increasing global liquidity has reduced banks' cost of funds in recent years in Turkey's economy. These developments have led to an increase in tourist consumption together with demand for consumer loans.

There are significant relationships between the increase in consumer loans and the increase in tourism demand. In recent years, the decline in interest rates has been an important factor in the growth of domestic demand. Therefore, this development has been effective in the increase in the domestic tourism demand and allowing nationals to travel more often in recent years.

Annual average increase rate of foreign visitors is $9.17 \%$ for the last 11 years. In the same period, the rate of increase in international tourism income is $8.83 \%$. Thus the rate of increase in international tourism revenue has remained low than $0.34 \%$ from the rate of increase in the number of visitors in the past 11 years. On the other hand, average increase rate of travels abroad from Turkey is $7.44 \%$ and annual increase in foreign tourism expenditure is $8.04 \%$ in the last 11 years. These finding indicate that there is a significant increase in both internal and external tourism revenues and expenses with the exception of some years in the past 11 years. These growth rates are quite high when compared with the growth rate in world GDP of $2.7 \%$ between the years of 2000-2011 and $4.98 \%$ in Turkey's economy between the years of 2003-2013.

Despite the reduction in domestic spending in some years, the upward trend continued in internal tourism demand among Turkisch citizens. The annual increase rate is $2.97 \%$ for domestic travels in the last 5 years. In contrast, the annual increase in domestic tourism spending is $10.8 \%$ in the same period. These results show that citizens traveling abroad have spent much more in the same period.

The average annual spending associated with tourist consumption is increased $1.3 \%$ in the past 5 years in 
Turkey. In contrast, mandatory consumption expenditures are decreased $-1.7 \%$ in the same period. These data indicate that increase in tourist consumption expenditures will be continuing in the coming years.

Consumer loans are an effective source of financing for tourist consumption. These loans are offered by banks to meet the cash needs of consumers. Maturity and interest rate of travel credits vary according to the bank.

The type of loans which can be associated directly with the tourist consumption is the travel credit that granted under individual needs. But there is no organization that publishes statistical data related to the travel credit in Turkey. Therefore, it is difficult to establish a direct relationship between changes in travel credit and tourist consumption expenditure.

Implementing the individual risk report contribute to the solution of the problems encountered for consumer loans in recent years in Turkey. Individual credit risk report that including individuals credit score is a report which outlines individual credit deals in the banking sector. These reports and scores are used all kinds of consumer loans including travel credit and credit cards that are allocated to individuals by banks. The application of credit rating affect credit limit, interest and costs in Turkey. Implementing long term sales policies for customers who have positive credit record and payment habits, will be effective in reducing risk in the tourism sector.

Annual increase rate of consumer lending is $39.47 \%$ in the last 11 years. This rate is much higher than the optimal increase $17 \%$ in loans that calculated for Turkey's economy by Ekinci (2010). Annual increase in international tourism expenditure is $8.04 \%$ in the same period. The increase in domestic tourism spending is $10.8 \%$ followed by TurkStat since 2009 for the last four years. These rates are much below than the increase $39.47 \%$ in installment loans' growth. In other words, the figures show that despite the high increases in consumer loans, this increase are not emerging adequately in tourist consumption.

The annual average growth rate of consumer loans is $31.9 \%$ for the last nine years. This rate is below than the increase in installment loans of $45.0 \%$. But it is quite high than $13.15 \%$ increase in GNP at current price, $10.8 \%$ increase in the domestic tourist consumption expenditures and $8.04 \%$ increase in foreign tourist consumption expenditures. In other words, it is understood that this high increase in consumer loans arise from out of travel credits.

The average annual increase in per capita income is 5.74\% the years between 2005-2013 in Turkey. In the same period, the elasticity is 5.01 depend on change in the demand for consumer loans comparing with the income per capita. These results indicate that credit demand is extremely sensitive to income increases in Turkey. No doubt the same will be true for travel loan demand sensitivity.

\section{Discussion}

One of the main limitations of this study is the lack of data about the consumer loans used directly for tourist consumption. As such, the results may not be generalizable for travel credit. Another limitation is the lack of the data related to domestic tourism expenditure. A study that includes travel credit and tourist consumption would be more desirable. The study also notes that the relationship between economic growth and tourist consumption. But the benefits considered were limited. A more expansive study would probably have more results. This would also allow better understanding about credit loans that can be used for tourist consumption.

\section{Conclusion}

Economic stability, decline inflation and falling interest rates promote consumer loans in an economy. This study offers findings about consumer credit loans regarding tourist consumption. Our findings show that increase in consumer credit promotes tourist consumption. Tourist consumption and credit usage have been increasing regularly in recent years as a result of positive developments in the macroeconomic indicators in Turkey. However, despite the high increases in consumer loans in the last 10 years, these increases are not emerging adequately in tourist consumption in Turkey. Our figures contributed to this outcome.

\section{References}

[1] Usal, A. and Oral, S. (2001). Turizm Pazarlamasi. Kanyilmaz Matbaasi, Izmir.

[2] Hacioglu, N. (1997) Turizm Pazarlamasi. Uludag Universitesi Basimevi, Bursa.

[3] Icöz, O. (1996) Turizm Isletmelerinde Pazarlama: Ilkeler ve Uygulama. Anatolia Yayincilik, Ankara.

[4] Olali, H. ve Timur, A. (1988) Turizm Ekonomisi. Ofis Ticaret Matbaacilik, Izmir. 
[5] Foscht, F., Maloles, C., Swoboda, B and Chia, S.-L. (2010) Debit and Credit Card Usage and Satisfaction. International Journal of BankMarketing, 28, 150-165. http://dx.doi.org/10.1108/02652321011018332

[6] Banking Supervision and Regulation Agency (2012) Financial Market Report. December 2012, Number 28. https://www.bddk.org.tr/WebSitesi/turkce/Raporlar/Finansal_Piyasalar_Raporlari/11902fpr_aralik2012_29032013bb.p df

[7] TurkStat (2014) Tourism Statistics. 30 January 2014 dated TurkStat News Bulletin, Number: 15885. http://www.tuik.gov.tr/PreHaberBultenleri.do?id=15885

[8] World Bank (2013) World Development Indicators 2013. http://databank.worldbank.org/data/download/WDI-2013-ebook.pdf

[9] TurkStat (2015) Statistical Figures. Expenditure on the Gross Domestic Product (at 1998 Prices). http://www.tuik.gov.tr/PreTablo.do?alt_id=1063

[10] Turkisch Statistic Institute (TurkStat) (2014) Tüketim Harcamalari, Yoksulluk ve Gelir Dağilimi: Sorularla Resmi İstatistikler Dizisi-6. www.tuik.gov.tr/IcerikGetir.do?istab_id=156

[11] Tari, R. and Pehlivanoglu, F. (2007) Kocaeli Ilinde Tuketici Davranislarinin Gelir-Harcama GruplariIliskisi Acisindan Analizi. Kocaeli University Journal of the Institute of Social Sciences, 13, 192-210.

[12] Consumer Spending Statistics (2014) http://www.statisticbrain.com/what-consumers-spend-each-month/

[13] Gul, K. (2008) Turizm Piyasasinda Fiyat Olusumu. Turizm Ekonomisi, Lisans Yayincilik, Istanbul.

[14] Turkisch Statistic Institute (2014) TurkStat News Bulletin, 07 May 2014, Number: 15890. http://www.tuik.gov.tr/PreHaberBultenleri.do?id=15890

[15] Kredi Dunyasi (2013) Ihtiyac Kredisi. http://kredidunyasi.com.tr/g/ihtiyac-kredisi

[16] Kurul, D.M. (2012) Akim Verilerle Tuketici Kredileri, Economic Notes of Central Bank. 35, 1-8.

[17] Asia Pasific (2004) South Korea’s Overburdened Consumers. Asia Pasific, 13, 5-6.

[18] Mercan, M. (2013) Kredi Hacmindeki Degisimlerin Ekonomik Buyumeye Etkisi: Turkiye Ekonomisi Icin Sinir Testi Yaklasimi. Bankacilar Dergisi, 84, 54-71.

[19] Iscan, A. (2003) Banka Kredilerindeki Daralmanin Ekonomik Etkileri ve Krizlerdeki Gelisimi. Professional Qualification Thesis, Central Bank, Banking and Financial Institutions Departmant, Ankara.

[20] Hoti, S., McAler, M. and Shareef, R. (2005) Modelling International Tourism and Country Risk Spillovers for Cyprus and Malta. Working Paper: 516, SAFE and FIMARC Working Series, Cowan University, Perth.

[21] Inag, N. (1990) Tuketici Kredileri. Notification No 9011, Central Bank of Republic of Turkey; Research, Planning and Education Department, Ankara.

[22] Tekirdag, A. (2009) Turkiye’de Bireysel Kredi Artisi ve Risk Analizi. Professional Qualification Thesis, Central Bank, Banking and Financial Institutions Department, Ankara.

[23] Chien, Y. and Devaney, S.A. (2001) The Effects of Credit Attitude and Socioeconomic Factors on Credit Card and Installment Debt. The Journal of Consumer Affairs, 35, 162-179. http://dx.doi.org/10.1111/j.1745-6606.2001.tb00107.x

[24] Ibicioglu, M. and Karan, M.B. (2009) Turkiye'de Faiz Oranlarinin Tuketici Kredileri Uzerindeki Etkisi. BDDK Bankacllık ve Finansal Piyasalar, 3, 11-30.

[25] Sagkol, E., Cetinkaya, E., Mazmanci, H., Kayci, I., Isikli, K., Celik, M., Kucuk, R., Atalay, S., Sagut, S., Sunerin, S. and Sevinc, V.U. (2013) Kredi Riski Azaltim Tekniklerine Iliskin Teblig Serhi. BAT Publication No 298, Banks Association of Turkey, Ankara.

[26] Tura Turizm (2014) Kampanya: Tatil Kredisi. http://www.turaturizm.com.tr/kampanya

[27] Kucukozmen, C. (2014) Risk Yonetiminde Sesi Az Duyulan Bir Devrim KKB. Credit Record Bureau Bulletin February 2014. http://www.coskunkucukozmen.com/wp-content/uploads/2012/01/03.pdf

[28] Nelson, A.A. (2010) Credit Scores, Race, and Residential Sorting. Journal of Policy Analysis and Management, 29, 3968. http://dx.doi.org/10.1002/pam.20478

[29] Your Credit Score and Credit Card Rewards: 10 Tips. http://www.getrichslowly.org/blog/2013/04/07/your-credit-score-and-credit-card-rewards-10-tips/

[30] Kredi Kayit Burosu (2013) KKB Kredi Notu. http://www.kkb.com.tr/btr/ürünler/kkb-kredi-notu.aspx

[31] Peterson, R.L. (1983) Usury Laws and Consumer Credit: A Note. Journal of Finance, 38, 1299-1304. http://dx.doi.org/10.1111/j.1540-6261.1983.tb02299.x

[32] Hofmann, C. (2012) Stabilizing the Financial Sector: EU Financial Services 2010-2012. European Review of Contract Law, 8, 426-455. 
[33] Ekinci, A. (2013) Turkiye Icin Optimal Kredi Buyume Orani Ne Olmalidir? Bankacilar Dergisi, 85, 81-91.

[34] Banking Supervision and Regulation Agency (2014) Turkisch Banking Sector Overview-December 2013, Number 2014/1.

[35] European Central Bank (2013) The Eurosystem Household Finance and Consumption Survey Results from the First Wave. ECB Statistics Paper Series No 2.

[36] Haber 7. (2014) Ekotrent: Yasak Etkisini Gosterdi. http://ekonomi.haber7.com/finans/haber/1129990-yasak-etkisini-gosterdi-15-milyar-lira-azaldi

[37] Bankalar (2013) Tatil Kredileri. http://www.bankalar.org/krediler/ihtiyac-kredileri/tatil-kredisi

[38] Kredikredi (2013) Kuveyt Türk TL Seyahat Kredisi. www.kredikredi.com/kredi-detaylari/ihtiyac/91/kuveyt_turk_tl_seyahat_kredisi.htm

[39] Turkey Travel Agencies Association (2013) Yapi Kredi Bankasi Turizm Sektor Kampanyasi. www.tursab.org.tr/tr/tursab/ihtisas-komiteler/iata-komitesi/komite-duyurulari/yapi-kredi-bankasi-turizm-sektor-kampa nyasi 7391.html 
Scientific Research Publishing (SCIRP) is one of the largest Open Access journal publishers. It is currently publishing more than 200 open access, online, peer-reviewed journals covering a wide range of academic disciplines. SCIRP serves the worldwide academic communities and contributes to the progress and application of science with its publication.

Other selected journals from SCIRP are listed as below. Submit your manuscript to us via either submit@scirp.org or Online Submission Portal.
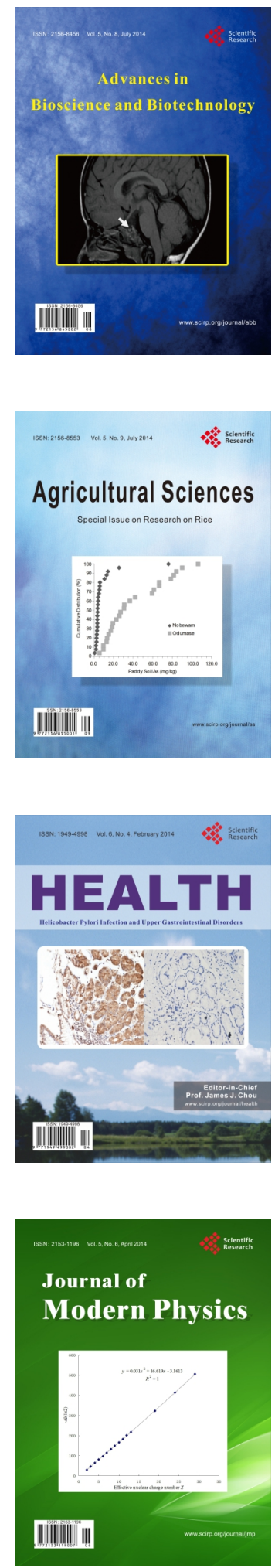
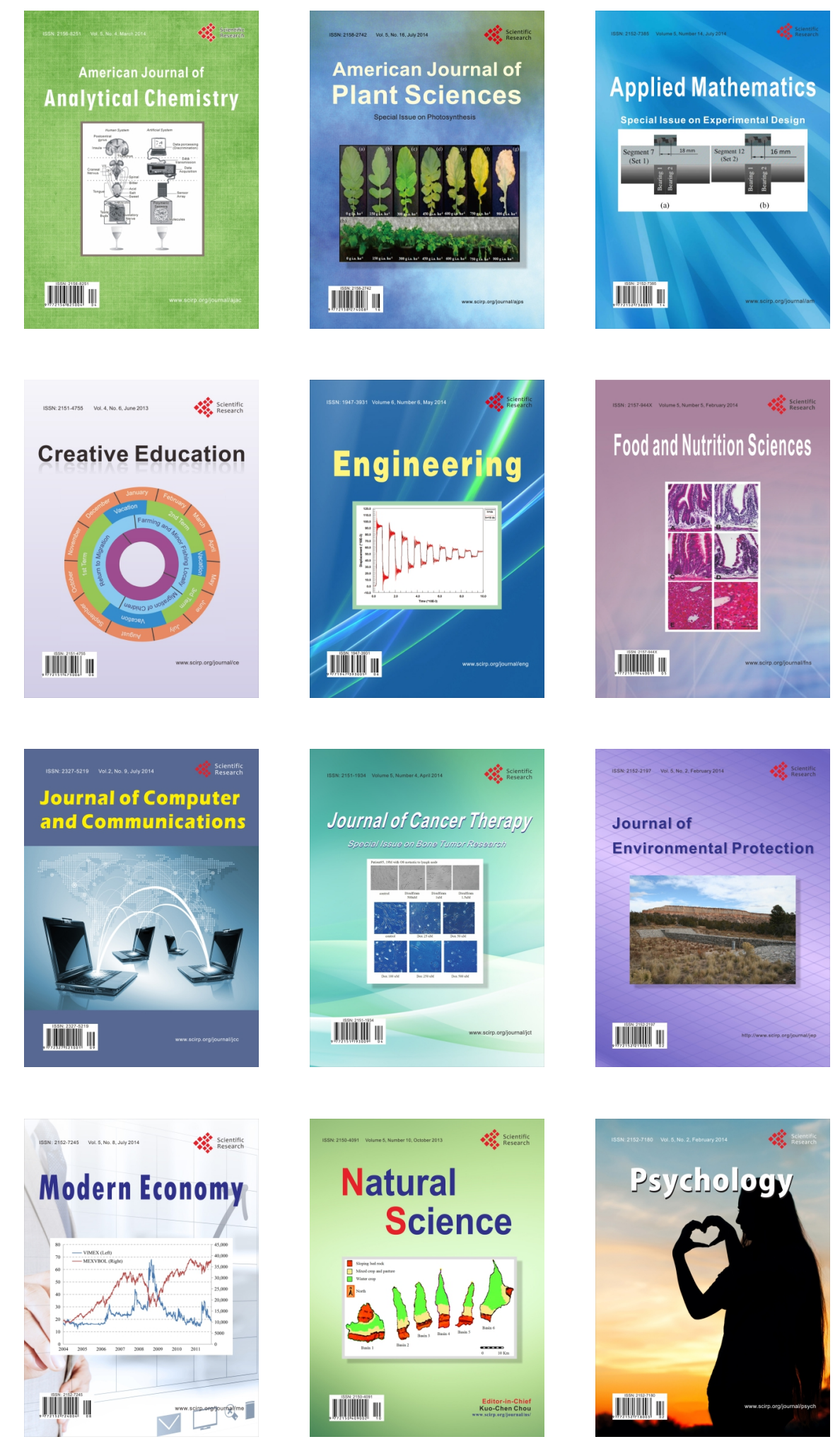